\title{
Cloning and tissue distribution of novel splice variants of the ovine ghrelin gene
}

\author{
Moira Menzies ${ }^{1 \dagger}$, Inge Seim ${ }^{2 \dagger}$, Peter Josh ${ }^{1,2}$, Shivashankar H Nagaraj ${ }^{3}$, Michael Lees ${ }^{1}$, Carina Walpole², \\ Lisa K Chopin ${ }^{2 *}$, Michelle Colgrave ${ }^{1}$ and Aaron Ingham ${ }^{1}$
}

\begin{abstract}
Background: The ghrelin axis is involved in the regulation of metabolism, energy balance, and the immune, cardiovascular and reproductive systems. The manipulation of this axis has potential for improving economically valuable traits in production animals, and polymorphisms in the ghrelin (GHRL) and ghrelin receptor (GHSR) genes have been associated with growth and carcass traits. Here we investigate the structure and expression of the ghrelin gene (GHRL) in sheep, Ovis aries.

Results: We identify two ghrelin mRNA isoforms, which we have designated $\Delta$ ex2 preproghrelin and $\Delta$ ex2,3 preproghrelin. Expression of $\Delta$ ex2,3 preproghrelin is likely to be restricted to ruminants, and would encode truncated ghrelin and a novel C-terminal peptide. Both $\Delta$ ex2 preproghrelin and canonical preproghrelin mRNA isoforms were expressed in a range of tissues. Expression of the $\Delta$ ex2,3 preproghrelin isoform, however, was restricted to white blood cells (WBC; where the wild-type preproghrelin isoform is not co-expressed), and gastrointestinal tissues. Expression of $\Delta$ ex2 preproghrelin and $\Delta$ ex2,3 preproghrelin mRNA was elevated in white blood cells in response to parasitic worm (helminth) infection in genetically susceptible sheep, but not in resistant sheep.
\end{abstract}

Conclusions: The restricted expression of the novel preproghrelin variants and their distinct WBC expression pattern during parasite infection may indicate a novel link between the ghrelin axis and metabolic and immune function in ruminants.

\section{Background}

The peptide hormone ghrelin has a wide range of physiological functions, including a role in appetite stimulation, and energy balance and regulation of the immune and reproductive systems [1-4]. Ghrelin is most abundantly expressed in the stomach of monogastrics and the abomasum (glandular stomach) of ruminants, and it is also expressed in a wide range of other tissues [3,5-7]. In order to bind and activate its cognate receptor, the growth hormone secretagogue receptor 1a (GHSR1a), ghrelin is posttranslationally octanoylated by the enzyme ghrelin-O-acyl transferase (GOAT) $[8,9]$.

The ghrelin axis (which includes ghrelin, GHSR, and GOAT) is a potential target for improving production in ruminant species through the manipulation of feeding,

\footnotetext{
*Correspondence: I.chopin@qut.edu.au

${ }^{+}$Equal contributors

${ }^{2}$ Ghrelin Research Group, Translational Research Institute, Institute of Health \& Biomedical Innovation and APCRC-Q, Queensland University of

Technology, 37 Kent St., Woolloongabba, Brisbane, QLD, Australia

Full list of author information is available at the end of the article
}

growth, body composition and immune and reproductive functions [10-12]. Ghrelin or GHSR polymorphisms have been associated with enhanced food intake, growth and body conformation in cattle [13,14], and GHSR polymorphisms have been associated with carcass traits in sheep [10]. GHSR mRNA expression was elevated in the pituitary gland of a line of sheep selected for increased fat cover, compared to a lean sheep selection line [15]. Ghrelin and GHSR1a are thought to regulate reproduction in many species and are expressed in reproductive tissues of sheep [16-18].

We previously reported differential ghrelin expression in the gut (mRNA) and blood (peptide) of sheep selected for gastrointestinal nematode resistance compared to susceptible sheep [19], suggesting that ghrelin may play a role in the immunity to parasite infection. Here, we report a detailed characterization of the ghrelin gene (GHRL) in the sheep, Ovis aries, and the discovery of novel ghrelin variants with distinct mRNA expression in white blood cells in response to helminth infection. 


\section{Results and discussion}

\section{Ghrelin gene structure}

Partial structure and sequence of the ghrelin gene (GHRL) has been determined in a number of ruminants including cattle [20], sheep [21], goat [22] and water buffalo [23], however, no complete gene structure exists for the sheep gene. To investigate ghrelin gene structure and expression in the sheep, 5' RLM-RACE and RT-PCR (using primers spanning the canonical exons 1 to 4 of preproghrelin) were performed using abomasum (glandular stomach) and white blood cells (WBC). For consistency, we follow the exon numbering nomenclature of the human and murine GHRL genes [24,25]. Sequence analysis of $5^{\prime}$ RLM-RACE products revealed two alternative transcriptional start sites (TSS) present in a short $5^{\prime}$ untranslated exon, 13-20 bp in length, which was previously termed exon 0 (Figure $1 \mathrm{~A}$ and $\mathrm{B}$ ). These TSS were found in both the abomasum and WBC.

Using RT-PCR we demonstrated that the canonical preproghrelin variant (305 bp) is expressed in the abomasum and white blood cells (Figure 1C). Sequencing confirmed that this $305 \mathrm{bp}$ RT-PCR product consisted of 4 exons and the corresponding full-length transcript would encode a 116 amino acid preproghrelin protein, identical to the sheep reference sequence [GenBank: NM_001009721]. The canonical coding exons of the ovine ghrelin gene are exons 1 (135 nt), 2 (114 nt), 3 (109 nt) and 4 ( 150 nt). Although the predominant form of preproghrelin is 117 amino acids (AA) in length and mature ghrelin is $28 \mathrm{AA}$ in most mammals, the ruminant form of preproghrelin is 116
AA and ghrelin is a 27 AA peptide, resulting from alternative splicing which removes a codon for glutamine [20,22,26-28].

Two additional RT-PCR products, $191 \mathrm{bp}$ and $82 \mathrm{bp}$ in size, were also amplified (Figure $1 C$ ). Sequencing revealed that the 191 bp mRNA isoform [GenBank: JQ655468] lacks exon 2 and has been designated $\Delta$ ex2 preproghrelin. Translation of $\Delta \mathrm{ex} 2$ preproghrelin would produce a 78 amino acid peptide, consisting of the preproghrelin signal peptide, followed by a 55 amino acid peptide that includes a C-terminally truncated ghrelin peptide (13 amino acids) and the obestatin sequence (which is encoded by exon 3) (Figure 1D). Interestingly, although exon 2 is absent from the $\Delta$ ex 2 preproghrelin mRNA sequence, the open reading frame is conserved in mammals (Figure 2A). Obestatin, a peptide hormone derived from the ghrelin preprohormone [29], has independent functions from its sibling peptide, including autocrine/paracrine roles in the pancreas and adipose tissue [30].

The 82 bp amplicon [GenBank: JQ655469] lack exons 2 and 3 and has been designated $\Delta$ ex2,3 preproghrelin. Like exon 2-deleted preproghrelin, it is predicted that translation of this variant would produce an 81 amino acid peptide that contains the preproghrelin signal peptide, followed by the first 13 amino acids of the mature ghrelin peptide (Figure 1D). A unique 45 amino acid Cterminal peptide (lacking obestatin) is predicted to follow, as removal of the non-symmetrical exon 3 creates a frame shift. In contrast to $\Delta \mathrm{ex} 2$ preproghrelin which is

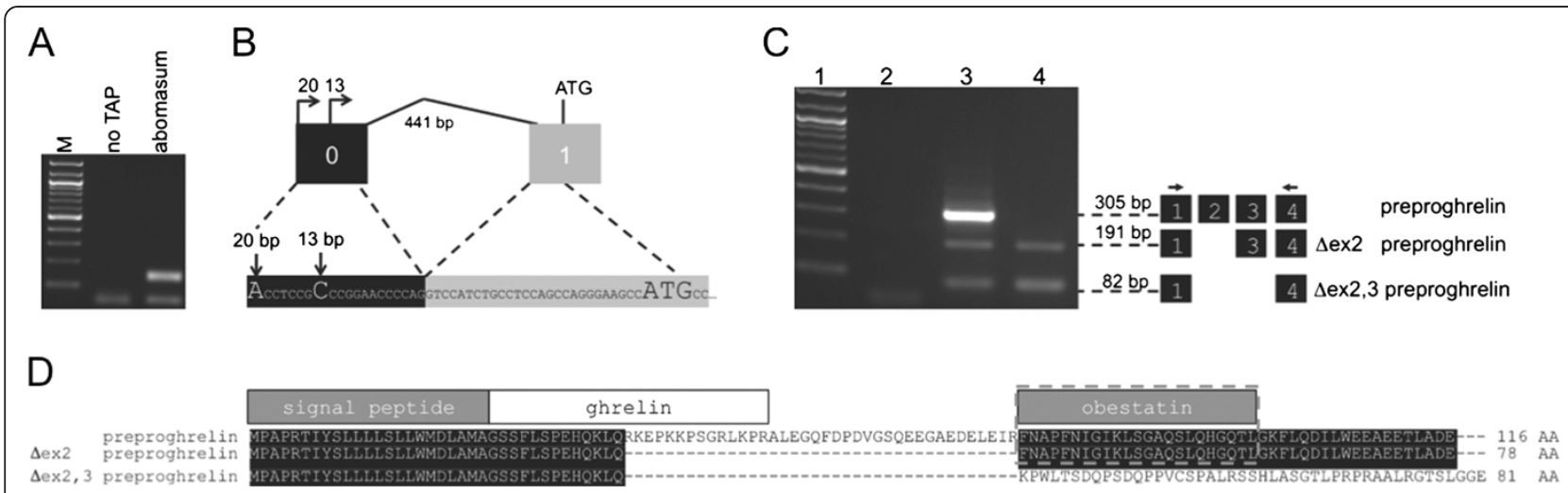

Figure 1 Characterization of the sheep ghrelin gene. (A) Identification of the ovine GHRL transcription start sites. 5' RLM-RACE of abomasum. $M=$ NEB molecular weight marker 100; no TAP = negative TAP control. (B) Partial transcript sequence showing exon 0 and exon 1 . GHRL exon 0 is shown as a black box, exon 1 as a grey box, introns as horizontal lines. Transcription start sites in exon 0 are capitalized. Size (bp) are shown above each exon. The translation initiation site of preproghrelin is shown as ATG. (C) Ethidium bromide stained agarose gel showing the expression of ghrelin (305 bp), exon 2-deleted preproghrelin ( $\Delta$ ex2 preproghrelin, 191 bp) and exon 2,3-deleted preproghrelin ( $\Delta$ ex2,3 preproghrelin, 82 bp) amplified from the abomasum (Lane 3) and white blood cells (Lane 4) of sheep. The exon structure corresponding to each RT-PCR product is depicted by the adjacent boxes, and the positions of RT-PCR primers are indicated by arrows above exons. Lane 1 contains a 100 bp molecular weight marker and Lane 2 the no template control. (D) Predicted translation and alignment of sheep preproghrelin variants. The signal peptide, ghrelin and obestatin are shown as boxes above corresponding coding sequences. Wild-type preproghrelin code for a 27 amino acid (AA) ghrelin peptide, while $\Delta$ ex2 preproghrelin and $\Delta$ ex2,3 preproghrelin code for a truncated 13 AA ghrelin peptide. Obestatin peptide (sequence indicated by a dotted line) is encoded by the C-terminus of the wild-type preproghrelin and $\Delta$ ex2 preproghrelin, whereas $\Delta$ ex2,3 preproghrelin has a unique 45 amino acid carboxyl terminal sequence. 

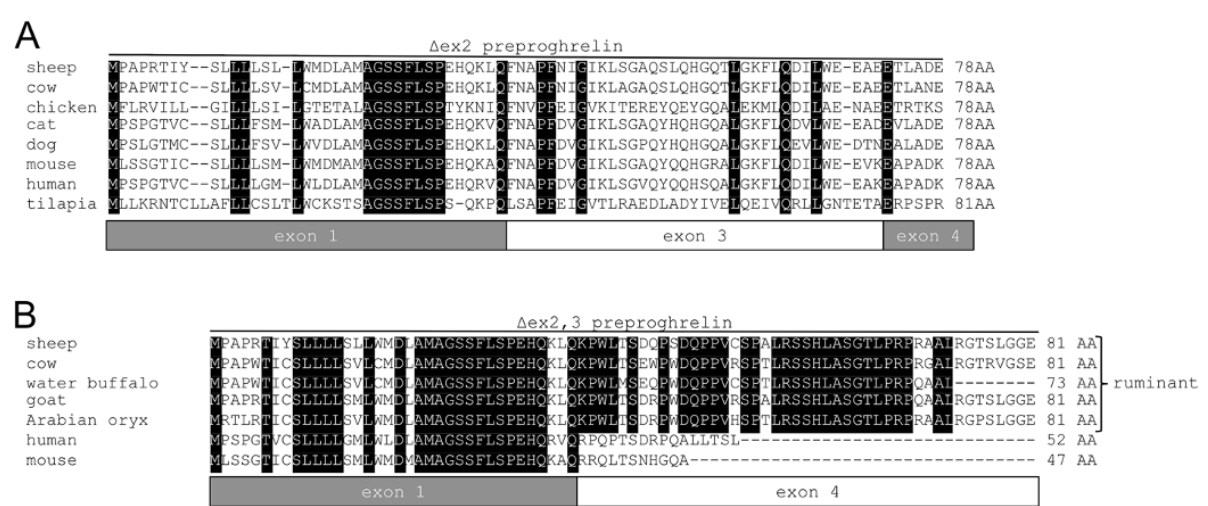

Figure 2 Alignment of $\Delta$ ex2,3 preproghrelin and $\Delta$ ex2,3 preproghrelin. Alignment of (A) $\Delta$ ex2,3 preproghrelin and (B) $\Delta$ ex2,3 preproghrelin peptide sequences. The exonic structure containing the sequence coding for the peptide is shown below the sequence. Downstream exon 4 sequence data was not available for the water buffalo and $\Delta$ ex2,3 preproghrelin for this species is shown as 73 amino acids.

conserved in mammals, only ruminants of the Bovidae family harbor an intact $\Delta$ ex2,3 preproghrelin open reading frame (Figure 2B). This include sheep, goat, cow, the water buffalo (Bubalus bubalis), and the antelope Arabian oryx (Oryx leucoryx). The 45 amino acid peptide sequence of $\Delta$ ex2,3 preproghrelin does not present any known sequence motifs that could indicate its possible function (data not shown).

\section{Expression of preproghrelin variants and the ghrelin acylation enzyme in ovine tissues}

The tissue distribution of ghrelin in sheep has been reported previously [21]. In the earlier study, RT-PCR primers spanned exons 2 and 4 of the ghrelin gene, excluding the possible amplification of the $\Delta$ ex2 preproghrelin and $\Delta$ ex2,3 preproghrelin variants. We screened 20 different cell and tissue types for wild-type preproghrelin transcript, the two novel preproghrelin variants and the ghrelin acylation enzyme GOAT (encoded by MBOAT4) using RT-PCR. We found that the expression of wildtype preproghrelin and the novel splice variants was tissue specific (Table 1). Full-length preproghrelin was expressed in all tissues examined, with the exception of the urinary bladder, skeletal muscle and WBC (Table 1). $\Delta$ ex2 preproghrelin expression was also detected in many tissues, including the gastrointestinal tract (abomasum, small intestine, colon), lymphoid tissue (lymph nodes and Peyer's patches), lung, WBC, and urinary bladder (Table 1). Interestingly, the expression of $\Delta \mathrm{ex} 2,3$ preproghrelin was restricted to $\mathrm{WBC}$, abomasum, small intestine and lymphoid tissue associated with the small intestine. The enzyme GOAT, (encoded by the gene $M B O A T 4$ ) catalyses the octanoylation of ghrelin, allowing it to signal through its cognate receptor, GHSR1a $[8,9]$. GOAT is expressed in the abomasum (glandular stomach) and pancreas in sheep, and expression has been demonstrated in equivalent tissues in other species
$[8,9,31]$. GOAT expression was not detected in a number of sheep tissues that expressed ghrelin variants, including white blood cells, lung and venous tissue (Table 1), suggesting that the ghrelin peptide or ghrelin peptide variants expressed in these tissues are not acylated.

Table 1 Tissue distribution of 'wild-type' preproghrelin, the $\Delta$ ex2 preproghrelin and $\Delta$ ex2,3 preproghrelin variants (encoded by GHRL), and GOAT (encoded by MBOAT4) in sheep, determined using qualitative RT-PCR

\begin{tabular}{|c|c|c|c|c|}
\hline Tissue & Preproghrelin & $\begin{array}{l}\Delta \text { ex } 2 \\
\text { preproghrelin }\end{array}$ & $\begin{array}{l}\Delta \text { ex } 2,3 \\
\text { preproghrelin }\end{array}$ & GOAT \\
\hline Aorta & + & - & - & - \\
\hline Abomasum & + & + & + & + \\
\hline Bladder & - & + & - & - \\
\hline Colon & + & + & - & + \\
\hline Heart muscle & + & - & - & + \\
\hline Hypothalamus & + & + & - & - \\
\hline Kidney & + & - & - & + \\
\hline Large intestine & + & + & - & + \\
\hline Liver & + & + & - & + \\
\hline Lung & + & + & - & + \\
\hline MLN & + & + & - & + \\
\hline Pancreas & + & + & - & + \\
\hline Salivary gland & + & - & - & + \\
\hline Skeletal muscle & - & - & - & + \\
\hline Small intestine & + & + & + & + \\
\hline Spleen & + & - & - & + \\
\hline Trachea & + & - & - & - \\
\hline Tooth & + & + & - & + \\
\hline Vein & + & + & - & - \\
\hline $\begin{array}{l}\text { White blood } \\
\text { cells }\end{array}$ & - & + & + & - \\
\hline
\end{tabular}

MLN denotes Mesenteric Lymph Node. + = expressed. - = not detected. 
The unmodified form of ghrelin, desacyl ghrelin (or desghrelin), is also functional, but acts through an unidentified alternative ghrelin receptor in some cell and tissues [32].

\section{The $\Delta$ ex2 preproghrelin and $\Delta \mathrm{ex} 2,3$ preproghrelin} variants are responsive to parasite infection

We noted that white blood cells expressed $\Delta$ ex 2 preproghrelin and $\Delta$ ex2,3 preproghrelin, but not wild-type preproghrelin transcripts (Figure $1 \mathrm{C}$ and Table 1). On the basis of these findings, we hypothesized that preproghrelin variants may be differentially expressed in response to parasitic worm (helminth) infection. Blood samples were generated in an earlier experiment in which sheep from the parasite resistant and susceptible lines of a selection flock were challenged with the highly pathogenic nematode, Haemonchus contortus [33]. Expression of $\Delta \mathrm{ex} 2$ preproghrelin and $\Delta$ ex2,3 preproghrelin was determined in white blood cells $(\mathrm{WBC})$ at a number of time points after infection (Figure 3A and B). While the wild-type preproghrelin was not amplified in any WBC samples (data not shown), expression of both novel preproghrelin variants increased in WBC in susceptible sheep 4 days after infection. From day 10, expression of the variants remained constant.

Having established that the novel $\Delta$ ex 2 preproghrelin and $\Delta$ ex2,3 preproghrelin variants display a distinct expression pattern in white blood cells following parasite infection, we interrogated the proximal promoter region of the sheep ghrelin gene. As outlined above, RLMRACE (Figure $1 \mathrm{~A}$ and $\mathrm{B}$ ) revealed that WBCs harbor a transcriptional start site in a short untranslated exon 0 . The sequence region upstream of exon 0 of ghrelin was analysed for possible promoter features and transcription factor binding sites. A candidate promoter region, which is conserved between sheep and cattle, was identified in the first $450 \mathrm{bp}$ upstream of exon 0 (Figure 3C). A TATA box likely to provide an RNA polymerase binding site for GHRL transcription initiation was present 25 bp upstream of exon 0. Putative binding sites for members of the Ccaat/Enhancer Binding Protein (CEBP), cAMP-responsive element binding proteins (CREB), Krüppel-like factor (KLF) and specificity factor (SP1F) transcription factor families were also identified in this region. Three putative KLF-binding sites are present in the promoter region within 450 base pairs of the GHRL transcriptional start site in sheep. KLF4 is highly expressed in the stomach and other cells and tissues, has a similar expression pattern to ghrelin and regulates human ghrelin gene expression in the human AGS stomach cell line [34]. The zinc finger transcription factor KLF4 interacts with CREB and plays a wide range of roles, including the regulation of cell growth and differentiation [34]. Interestingly, evidence is emerging that KLF4 is involved in the pathophysiology of inflammatory diseases, including parasite infection [35-38].

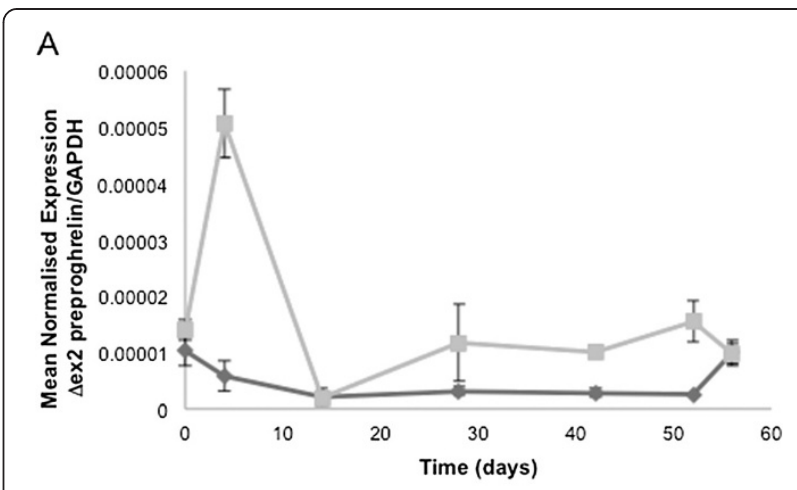

B

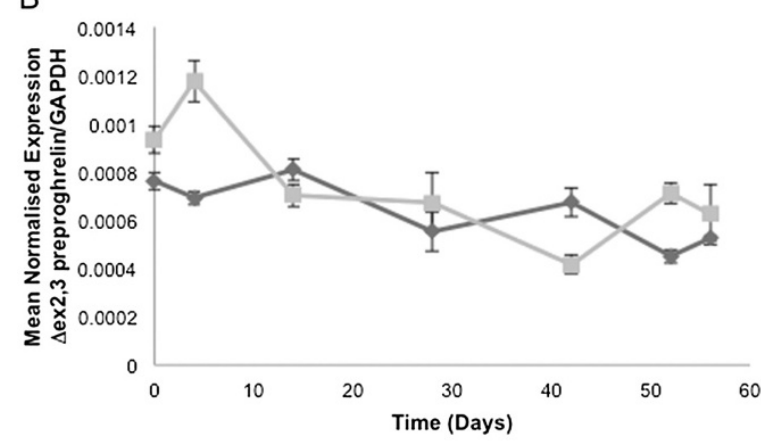

C

$$
\begin{aligned}
& \text {-450 AGCACAAGCCCCCAAGATCAMGTGACGATGCCTGGTTCATCACCGATTCC } \\
& \text {-400 ATGGACGT EACTTGGGCAAACTC GGGAGAQ EATGGATGAGGGATGGOG } \\
& \text {-350 ACG CTGGAGGTCTGCAGTCOGTGGGGTCGCAGAGAGTTGGACACAACTT } \\
& \text {-300 GGCAACT GAACAACAGCAACCGACCTGGTTCTAACCTAG ACAAGGAGG } \\
& \text {-250 EAGCAGCACGCCAGGCTGGCCCCAGA AGGAGGGGCAGGTAGCD TT } \\
& \text {-200 GGGCCGACOCAG CAACCCGGCCATCTCTCAGGGCATTTGA ETCTGCTG } \\
& \text {-150 ETGACGTCTCCC GGGGTGATGCGAGCCA TTTTAGTTCCCAAGGAA? } \\
& \text {-100 GGCACTCAGCCCCCGGATGCCAAGCTGCCCTGAGAGACGGCTGCTGGTTT } \\
& \text {-50 CAGACAAACACAGGCTGCC TATATAA GACCAGATGGOCGCCAGGCACC -1 } \\
& +1 \frac{A C C T C C G C C C G G A A C C C C A G}{B X O N O}
\end{aligned}
$$

Figure 3 Expression of ghrelin variants in white blood cells of sheep and overview of the proximal promoter region of the ovine ghrelin gene. Expression of ghrelin variant transcripts, $\Delta$ ex2 preproghrelin (A) and $\Delta$ ex2,3 preproghrelin (B) in white blood cells from genetically resistant (dark grey diamond symbol) or susceptible (light grey square symbol) sheep, following infection with Haemonchus contortus, demonstrated using real time RT-PCR. Results at each time point indicate mean and standard error from a group of 8 sheep. (C) Promoter region of the ovine ghrelin gene (GHRL). Predicted transcription factor binding sites are boxed and the transcription factor families that target this sequence are shown below the sequence. The transcription factor sites identified are also conserved in the promoter region of bovine ghrelin. The TATA box, a consensus sequence upstream of the transcription start site that plays a role in transcription initiation, and the first exon of the ghrelin gene (exon 0) are also shown. 
We speculate that KLF4 plays a role in regulating ghrelin expression in response to helminth infection.

\section{Variations on a theme: alternative splicing of the ghrelin gene}

A number of peptide preprohormones and neuropeptides are alternatively spliced to produce different isoforms, or peptides with different functions. It is now appreciated that the ghrelin gene locus is a polyhormone locus that, via alternative splicing and post-translational processing, produces a number of bioactive peptides [25,32]. The peptide hormone, obestatin, is derived from the ghrelin preprohormone [29] and has functions which are independent of ghrelin [30]. Other novel peptides derived from isoforms of the ghrelin preprohormone may also be functional [24,39-42].

We here describe two novel splice variants derived from the sheep ghrelin gene. Both $\Delta$ ex2 preproghrelin and $\Delta$ ex2,3 preproghrelin contain the conserved ghrelin GSSFL amino acid motif, which is the minimum sequence required for binding and stimulation of the ghrelin receptor GHSR1a in vitro [43] and for acylation of ghrelin by GOAT [44]. Although the truncated ghrelin variants are likely to have shorter half-lives than full-length ghrelin [45], these isoforms could have both endocrine effects (such as appetite stimulation), as well as autocrine/ paracrine actions in peripheral tissues.

A previous study conducted in our laboratory showed differential levels of ghrelin in the gut (mRNA) and blood (peptide) of sheep selected for gastrointestinal helminth resistance compared to susceptible sheep [19], suggesting that ghrelin is associated with immunity to parasite infection. Given a lack of wild-type preproghrelin and differential expression pattern in white blood cell noted between the resistant and susceptible sheep in the current study, these new variants are likely to play a role in immunity. In particular, the finding that the expression of the $\Delta \mathrm{ex} 2,3$ preproghrelin variant is limited to white blood cells and the gut, suggests that there is a direct link between tissues of the digestive tract and circulating immune cells. $\Delta$ ex 2,3 preproghrelin would be translated into a peptide that contains the minimal active region of ghrelin, and a novel 45 amino acid peptide.

\section{Conclusions}

Although further larger studies are required, we speculate that $\Delta \mathrm{ex} 2$ preproghrelin and $\Delta \mathrm{ex} 2,3$ preproghrelin are translated into bioactive peptides that function during the early stage of an effective response to gastrointestinal nematodes. In addition, the variants and their derived peptides may be useful in predicting susceptibility and resistance to parasitic infection. The recognition of novel preproghrelin variants should aid in interpreting studies linking expression of the ghrelin gene to phenotypic differences in ruminant production animals.

\section{Methods}

Animals

RNA samples from white blood cells and abomasum from Merino sheep challenged with Haemonchus contortus infection were generated for a previously reported study [33], as described below. This RNA was used for cloning of ghrelin variants and for characterization of ghrelin gene structure. All related procedures were approved by the F. D. McMaster Animal Ethics Committee, CSIRO Livestock Industries (AEC Approval No. 05/58). A range of tissues were collected from three euthanized $\mathrm{Me}$ rino sheep in accordance with the Australian Code of Practice for the Care and Use of animals for scientific purposes and Innovation Animal Ethics Committee (SA 2009/09/297) and used to determine the tissue expression of the ghrelin variants. Tissues were collected on ice, rapidly frozen using liquid nitrogen and stored at $-80^{\circ} \mathrm{C}$.

\section{RNA extraction and reverse transcription}

For each tissue sample, $50 \mathrm{mg}$ frozen tissue was wrapped in aluminum foil and immediately transferred to liquid nitrogen. For RNA extraction, the tissue was pulverized on a cold block using a hammer, scraped into RLT buffer (QIAGEN, Hilden, Germany) and immediately homogenized for $2 \times 60 \mathrm{~s}$ with $0.5 \mathrm{~mm}$ glass beads using a Mini-Beadbeater (Biospec Products, Bartlesville, OK). Total RNA was isolated from the homogenized tissues using an RNeasy Plus Mini kit (QIAGEN), with genomic DNA eliminator spin columns, according to the manufacturer's instructions. Total RNA $(2.5 \mu \mathrm{g})$ was subjected to a further DNase I digestion (amplification grade, Invitrogen, Carlsbad, CA) to ensure complete removal of genomic contamination. RNA 260:280 $\mathrm{nm}$ absorbance ratios were 1.9-2.0 and 260:230 $\mathrm{nm}$ ratios were between 2.0 and 2.2. For qualitative and quantitative RT-PCRs, cDNA was generated from $2 \mu \mathrm{g}$ total RNA by reverse transcription using oligo $(\mathrm{dT})_{20}$ primers and 200 units SuperScript III (Invitrogen) in a final volume of $20 \mu \mathrm{L}$ using a PTC-200 thermal cycler (MJ Research, Watertown, MA), according to the manufacturer's instructions. The resulting single-stranded cDNA was treated with ribonuclease $\mathrm{H}$ (Invitrogen).

\section{Identification of transcription start sites of the sheep ghrelin gene}

$5^{\prime}$ rapid amplification of cDNA ends (RACE) was undertaken using the FirstChoice RNA ligase mediated (RLM)-RACE kit (Invitrogen) according to the manufacturer's instructions. Briefly, $20 \mu \mathrm{g}$ total RNA was treated with $1.5 \mathrm{U}$ shrimp alkaline phosphatase (Fermentas, Glen Burnie, MD) in a $25 \mu$ l total reaction volume. Next, $10 \mu \mathrm{L}$ phosphatase treated RNA was treated with $5 \mathrm{U}$ 
tobacco acid pyrophosphatase (TAP, EPICENTRE Biotechnologies, Madison, WI) in a $50 \mu \mathrm{L}$ reaction to uncap intact RNA. The remaining $10 \mu \mathrm{L}$ was employed in a no-TAP control reaction, where TAP was substituted with water. RNA was purified using an RNeasy Mini cleanup kit (QIAGEN) and eluted in $12 \mu \mathrm{L}$ RNase-free water. Next, $0.3 \mu \mathrm{g} / \mu \mathrm{l}$ of $5^{\prime}$ RACE adapter (Ambion) was ligated to the eluted RNAs in a total volume of $30 \mu \mathrm{l}$ using $30 \mathrm{U}$ T4 RNA ligase (New England Biolabs, Ipswich, MA). Following a $16 \mathrm{~h}$ incubation at $17^{\circ} \mathrm{C}$ in a PTC-200 thermal cycler (MJ Research), the adapterligated RNA was purified (as before) and eluted in $10 \mu \mathrm{l}$. Adapter-ligated total RNA ( $2 \mu \mathrm{g})$ from the abomasum and white blood cells was reverse transcribed with 200 units SuperScript III (Invitrogen) using oligo $(\mathrm{dT})_{20}$ primers in a final volume of $20 \mu \mathrm{l}$, according to the manufacturer's instructions. All enzymatic (SAP, TAP, reverse transcription) reactions contained 40U RNasin Plus ribonuclease inhibitor (Promega, Fitchburg, WI). Following reverse transcription, the RACE-ready cDNA was treated with $2 \mathrm{U}$ of RNase $\mathrm{H}$ (Invitrogen) according to the manufacturer's instructions.

The first round of RT-PCR was performed with an adapter-specific forward primer and a GHRL-specific reverse primer $(5 \mathrm{OF} / \mathrm{R}$, Table 2$)$. The RT-PCR product $(1 \mu \mathrm{L})$ was diluted $1 / 10$ in water and then used in a secondary, nested RT-PCR (5IF/R, Table 2). RT-PCRs were performed in a total reaction volume of $50 \mu \mathrm{L}$ using $1 \mathrm{U}$ Platinum Taq Polymerase (Invitrogen), according to the manufacturer's instructions. RT-PCR products were purified using a PureLink PCR Purification Kit (Invitrogen), cloned into pTargeT (Promega), and transformed into TOP10 chemically-competent cells (Invitrogen). Sequencing reactions were performed using a BigDye Terminator Cycle Sequencing Kit v3 (Applied Biosystems, Foster City, CA, USA) on an ABI PRISM 3100-Avant Genetic Analyzer (Applied Biosystems), after pre-sequencing clean up of excess dye terminator with a CleanSEQ Sequencing Reaction Cleanup Kit (Agencourt Bioscience Corporation, Beverly, MA, USA).

\section{In silico promoter analysis}

The promoter region of the ovine ghrelin gene was annotated using the Genomatix (Munich, Germany) suite of programs. As the sheep genome sequence had yet to be released, the region upstream of exon 0 of the bovine GHRL gene was used for initial development of a promoter model. The MatInspector program was then used to identify possible transcription factor binding sites within each model. Stringent criteria were used in this stage of analysis with a minimum core similarity of 1 and matrix similarity of 0.9 selected. The bovine region was then aligned to the region upstream of the ovine GHRL gene transcriptional start site. Regions conserved between the bovine and ovine sequences were conserved candidate promoter elements.

\section{Non-quantitative expression of preproghrelin variants and the ghrelin acylation enzyme GOAT}

RT-PCR primers (Table 2) were designed to examine the splicing pattern of preproghrelin mRNAs (encoded by GHRL), as well as the expression of the ghrelin acylation

Table 2 Primer sequences used for qualitative and quantitative (q) real time RT-PCR, and RACE and the expected product size

\begin{tabular}{|c|c|c|c|c|c|}
\hline Primer name & Assay & Sequence $\left(5^{\prime}-3^{\prime}\right)$ & Exon position & Target gene & Amplicon sizes (bp) \\
\hline GHRL-1 F & RT-PCR & TTTCTGAGCCCTGAACATCAG & 1 & GHRL & 305 canonical (wild-type) preproghrelin \\
\hline GHRL-4R & & GAGAACAGACAGGTGGTTGG & 4 & & \\
\hline GHRL-5OF & RACE & ATGAATGAACACTGCGTTGCT & N/A & GHRL & 174 \\
\hline GHRL-5OR & & CAGTITCTGATGTTCAGGGCTC & 1 & & \\
\hline GHRL-5IF & RACE & GAACACTGCGTTTGCTGGCT & $\mathrm{N} / \mathrm{A}$ & GHRL & 130 \\
\hline GHRL-5IR & & GGCCAAGTCCATCCAGAGCA & 1 & & \\
\hline GHRL-2F & qRT-PCR & CTAAGAAGCCGTCAGGCAGACT & 2 & GHRL (preproghrelin) & 153 \\
\hline GHRL-2R & & GGGACTGAGCCCCTGACA & 3 & & \\
\hline GHRL1_3F & qRT-PCR & CAGAAACTGCAGTTCAATGC & $1 / 3$ & GHRL ( $\Delta$ ex2 preproghrelin) & 224 \\
\hline GHRL-4R & & CACGTGGTCTCGGAAGTGT & 4 & & \\
\hline GHRL1_4F & qRT-PCR & CTGCAGAAACCCTGGCTGA & $1 / 4$ & GHRL ( $\Delta \mathrm{e} \times 2,3$ preproghrelin) & 109 \\
\hline GHRL-4R & & CACGTGGTCTCGGAAGTGT & 4 & & \\
\hline GOAT-mF & qRT-PCR & GGTTTCAAGCTCGAGTTGAAGG & N/A & MBOAT4 (GOAT) & 212 \\
\hline GOAT-mR & & AGTAGGTGAGTTTGAGAGCCC & & & \\
\hline GAPDH-F & qRT-PCR & CCTGGAGAAACCTGCCAAGT & N/A & GAPDH & 209 \\
\hline GAPDH-R & & GCCAAATTCATTGTCGTACCA & & & \\
\hline
\end{tabular}


enzyme GOAT (encoded by MBOAT4). Preproghrelin variants were amplified using primers in the terminal coding exons (exons 1 and 4) of the canonical (wildtype) preproghrelin coding sequence. RT-PCRs were performed using $200 \mathrm{ng}$ cDNA, and $1 \mathrm{U}$ Platinum Taq HIFI Polymerase (Invitrogen) in a final volume of $50 \mu \mathrm{L}$ using a PTC-200 thermal cycler (MJ Research), according to the manufacturer's instructions. RT-PCR products were separated by electrophoresis on a $2 \%$ agarose gel in Tris-acetate-EDTA (TAE) buffer, stained with ethidium bromide and visualised using ultraviolet light.

RT-PCR products were purified using a PureLink PCR Purification Kit (Invitrogen), or a MinElute PCR Purification kit (QIAGEN), cloned into $p$ TargeT (Promega), and transformed into TOP10 chemically-competent cells (Invitrogen). Sequencing reactions were as outlined above.

\section{Bioinformatic alignment of ghrelin peptide variants}

Preproghrelin exon sequences were obtained by BLAST alignments [46] against nucleotide sequences available in the NCBI GenBank database. The recently released draft genome sequence (oryxL1) of the Arabian oryx (Oryx leucoryx) was obtained [47] and interrogated using a local instance of BLASTn available in v2.2.26+ of the BLAST + suite [48]. We acknowledge the efforts of the Weill Cornell Medical College in Qatar (WCMCQ) Genomics Core, the Biotechnology Centre of the Ministry of Environment (Qatar) and Wabra Wildlife Preservation (Qatar) in generating the oryx genome sequence. The obtained nucleotide sequences were converted to protein sequences using the ExPASy Translate tool [49] and aligned using MUSCLE [50].

\section{Quantitative real time reverse transcription (RT-)PCR}

Real time RT-PCR assays were designed to quantify expression of canonical ovine preproghrelin transcript (GHRE$2 \mathrm{~F} / 2 \mathrm{R}), \Delta \mathrm{ex} 2$ preproghrelin (GHRL1_3F/4R) and $\Delta \mathrm{ex} 2,3$ preproghrelin (GHRL1_4F/4R) in white blood cells (WBC) following infection with the parasitic helminth Haemonchus contortus (Table 2). Real time RT-PCRs for the housekeeping gene, glyceraldehyde 3-phosphate dehydrogenase $(G A P D H)$, were performed using the GAPDH-F/R primer pair, as previously described [51].

Briefly, white blood cells (WBC) were collected from Merino sheep exposed to a gastrointestinal helminth challenge with $H$. contortus, as outlined in a previous study [33]. Groups of 8 sheep bred for parasite resistance and 8 sheep bred for parasite susceptibility were individually dosed with a bolus of $5,000 \mathrm{H}$. contortus L3 infectious larvae (Kirby strain). Blood was collected immediately prior to infection (day 0 ) and on days 4, 14, 28 and 42 post-infection. White blood cells were isolated from each blood sample, RNA extracted and cDNA synthesized, as described above.
Real time RT-PCR was performed using the ABI Prism $7900 \mathrm{HT}$ sequence detection system (Applied Biosystems). Each reaction contained $1 \times$ SYBR Green Master Mix (Applied Biosystems), $900 \mathrm{nM}$ each primer and a constant amount of cDNA (corresponding to $10 \mathrm{ng}$ of reverse transcribed RNA for each sample). Three technical replicates were included for each candidate gene. For each of the biological samples, gene expression was quantified by normalizing each target gene against the expression of the reference gene, GAPDH, using the QGENE statistical analysis package [52]. Q-GENE calculates a Mean Normalised Expression $(\mathrm{MNE}) \pm$ Standard Error (SE), correcting for amplification efficiencies.

\section{Competing interests}

The authors declare that they have no competing interests.

\section{Authors' contributions}

Project design: IS, LKC, MC, Al. Sample collection and preparation: IS, PJ, CW, LKC; RNA extractions for non-quantitative PCR: IS and PJ; 5' RACE and cloning of ghrelin splice variants: IS; Bioinformatic alignment of preproghrelin variants: IS; RNA extractions and qRT-PCR for ghrelin variants in helminthchallenged sheep: MM, ML and Al; in silico promoter analysis: SHN. IS wrote the paper with significant contributions from Al and LKC and editorial input from all authors. All authors read and approved the final manuscript.

\section{Acknowledgements}

This work was supported by grants from National Health and Medical Research Council (NHMRC) (to LKC), the Cancer Council Queensland (to LKC), and the Queensland University of Technology (to LKC).

\section{Author details}

${ }^{1}$ CSIRO Animal, Food and Health Sciences, St Lucia, QLD, Australia. ${ }^{2}$ Ghrelin Research Group, Translational Research Institute, Institute of Health \& Biomedical Innovation and APCRC-Q, Queensland University of Technology, 37 Kent St., Woolloongabba, Brisbane, QLD, Australia. ${ }^{3}$ Queensland Centre for Medical Genomics, Institute for Molecular Bioscience, the University of Queensland, St Lucia, QLD, Australia.

Received: 21 February 2014 Accepted: 29 August 2014 Published: 6 September 2014

\section{References}

1. Baatar D, Patel K, Taub DD: The effects of ghrelin on inflammation and the immune system. Mol Cell Endocrinol 2011, 340(1):44-58.

2. Kaiya $H$, Kangawa K, Miyazato M: What is the general action of ghrelin for vertebrates? - comparisons of ghrelin's effects across vertebrates. Gen Comp Endocrinol 2013, 181:187-191.

3. Kojima M, Hosoda H, Date Y, Nakazato M, Matsuo H, Kangawa K: Ghrelin is a growth-hormone-releasing acylated peptide from stomach. Nature 1999, 402(6762):656-660.

4. Wren A, Small C, Ward H, Murphy K, Dakin C, Taheri S, Kennedy A, Roberts G, Morgan D, Ghatei M, Bloom SR: The novel hypothalamic peptide ghrelin stimulates food intake and growth hormone secretion. Endocrinology 2000, 141(11):4325-4328.

5. Date $Y$, Kojima M, Hosada H, Sawaguchi A, Mondal M, Suganama T, Matsukura S, Kangawa K, Nakazato M: Ghrelin, a novel growth hormone releasing acylated peptide is synthesised in a distinct endocrine cell type in gastrointestinal tracts of rats and humans. Endocrinology 2000, 141(11):4255-4261.

6. Gnanapavan S, Kola B, Bustin SA, Morris DG, McGee P, Fairclough P, Bhattacharya S, Carpenter R, Grossman AB, Korbonits M: The tissue distribution of the mRNA of ghrelin and subtypes of its receptor, GHS-R, in humans. J Clin Endocrinol Metab 2002, 87(6):2988.

7. Hayashida T, Murakami K, Mogi K, Nishihara M, Nakazato M, Mondal MS, Horii Y, Kojima M, Kangawa K, Murakami N: Ghrelin in domestic animals: 
distribution in stomach and its possible role. Domest Anim Endocrinol 2001, 21(1):17-24.

8. Gutierrez JA, Solenberg PJ, Perkins DR, Willency JA, Knierman MD, Jin Z, Witcher DR, Luo S, Onyia JE, Hale JE: Ghrelin octanoylation mediated by an orphan lipid transferase. Proc Natl Acad Sci U S A 2008, 105(17):6320-6325.

9. Yang J, Brown MS, Liang G, Grishin NV, Goldstein JL: Identification of the acyltransferase that octanoylates ghrelin, an appetite-stimulating peptide hormone. Cell 2008, 132(3):387-396.

10. Bahrami A, Miraei-Ashtiani SR, Mehrabani-Yeganeh $\mathrm{H}$ : Associations of growth hormone secretagogue receptor (GHSR) genes polymorphisms and protein structure changes with carcass traits in sheep. Gene 2012, 505(2):379-383.

11. Sugino T, Kawakita Y, Fukumori R, Hasegawa Y, Kojima M, Kangawa K, Obitsu T, Taniguchi K: Effects of glucose and amino acids on ghrelin secretion in sheep. Anim Sci J 2010, 81(2):199-204.

12. Wertz-Lutz $A E$, Jennings JS, Clapper JA: Plasma ghrelin concentrations of beef cattle consuming a similar amount of dietary energy supplied by different ingredients. J Anim Sci 2010, 88(7):2289-2299.

13. Komatsu M, Itoh T, Fujimori Y, Satoh M, Miyazaki Y, Takahashi H, Shimizu K, Malau-Aduli AE, Morita M: Genetic association between GHSR1a 5'UTRmicrosatellite and nt-7(C>A) loci and growth and carcass traits in Japanese Black cattle. Anim Sci J 2011, 82(3):396-405.

14. Sherman EL, Nkrumah JD, Murdoch BM, Li C, Wang Z, Fu A, Moore SS: Polymorphisms and haplotypes in the bovine neuropeptide $Y$, growth hormone receptor, ghrelin, insulin-like growth factor 2, and uncoupling proteins 2 and 3 genes and their associations with measures of growth, performance, feed efficiency, and carcass merit in beef cattle. J Anim Sc 2008, 86(1):1-16.

15. French MC, Littlejohn RP, Greer GJ, Bain WE, McEwan JC, Tisdall DJ: Growth hormone and ghrelin receptor genes are differentially expressed between genetically lean and fat selection lines of sheep. J Anim Sci 2006, 84(2):324-331.

16. Du C, Xilingaowa CG, Wang C, Li H, Zhao Y, Siqingaowa CJ: Expression of the orexigenic peptide ghrelin in the sheep ovary. Domest Anim Endocrinol 2009, 36(2):89-98.

17. Harrison JL, Adam CL, Brown YA, Wallace JM, Aitken RP, Lea RG, Miller DW: An immunohistochemical study of the localization and developmental expression of ghrelin and its functional receptor in the ovine placenta. Reprod Biol Endo 2007, 5:25

18. Miller D, Harrison J, Brown Y, Doyle U, Lindsay A, Adam C, Lea R: Immunohistochemical evidence for an endocrine/paracrine role for ghrelin in the reproductive tissues of sheep. Reprod Biol Endo 2005, 31(3):60.

19. Ingham A, Menzies M, Hunt $P$, Reverter A, Windon R, Andronicos N: Divergent ghrelin expression patterns in sheep genetically resistant or susceptible to gastrointestinal nematodes. Vet Parasitol 2011, 181(2-4):194-202.

20. Colinet FG, Portetelle D, Renaville R: Molecular characterization of the bovine GHRL gene. Arch Tierzucht 2009, 52(1):79-84.

21. Huang ZG, Xiong L, Liu ZS, Qiao Y, Dai R, Xie Z, Liu SR, Shi GQ, Liu GQ: The tissue distribution and developmental changes of ghrelin mRNA expression in sheep. Acta Genet $\operatorname{Sin} 2006,33(9): 808-813$.

22. Ida T, Miyazato M, Lin XZ, Kaiya H, Sato T, Nakahara K, Murakami N, Kangawa K, Kojima M: Purification and characterization of caprine ghrelin and its effect on growth hormone release. J Mol Neurosci 2010, 42(1):99-105.

23. Gil FM, de Camargo GM, de Souza FR P, Cardoso DF, Fonseca PD, Zetouni L, Braz CU, Aspilcueta-Borquis RR, Tonhati H: Polymorphisms in the ghrelin gene and their associations with milk yield and quality in water buffaloes. J Dairy Sci 2013, 96(5):3326-3331.

24. Seim I, Collet C, Herington AC, Chopin LK: Revised genomic structure of the human ghrelin gene and identification of novel exons, alternative splice variants and natural antisense transcripts. BMC Genomics 2007, 8:298

25. Seim I, Herington AC, Chopin LK: New insights into the molecular complexity of the ghrelin gene locus. Cytokine Growth Factor Rev 2009, 20(4):297-304.

26. Dickin JC, Thue TD, Buchanan FC: An alternative splice site in ghrelin is missing in ruminants. Anim Genet 2004, 35(5):411-412

27. Kandasamy S, Jain A, Baviskar P, Kumar R, Joshi P, Agarwal SK, Mitra A Molecular characterization and expression profile of ghrelin gene during different reproductive phases in buffalo (Bubalus bubalis). Domest Anim Endocrinol 2013, 45(2):55-63.

28. Zhang $A L$, Zhang $L$, Zhang $L Z$, Chen $H$, Lan $X Y$, Zhang $C L$, Zhang $C F$ : An efficient and rapid method for gene cloning from eukaryotic genomic DNA using overlap-PCR: With an example of cattle Ghrelin gene. Biochem Biophys Res Commun 2010, 391(3):1490-1493.

29. Zhang JV, Ren PG, Avsian-Kretchmer O, Luo CW, Rauch R, Klein C, Hsueh AJ: Obestatin, a peptide encoded by the ghrelin gene, opposes ghrelin's effects on food intake. Science 2005, 310(5750):996-999.

30. Seim I, Walpole C, Amorim L, Josh P, Herington A, Chopin L: The expanding roles of the ghrelin-gene derived peptide obestatin in health and disease. Mol Cell Endocrinol 2011, 340(1):111-117.

31. Lim CT, Kola B, Grossman A, Korbonits M: The expression of ghrelin Oacyltransferase (GOAT) in human tissues. Endocr J 2011, 58(8):707-710.

32. Seim I, Josh P, Cunningham P, Herington A, Chopin L: Ghrelin axis genes, peptides and receptors: recent findings and future challenges. Mol Cell Endocrinol 2011, 340(1):3-9.

33. Ingham A, Reverter A, Windon $R$, Hunt $P$, Menzies M: Gastrointestinal nematode challenge induces some conserved gene expression changes in the gut mucosa of genetically resistant sheep. Int J Parasitol 2008, 38(3-4):431-442.

34. Lee HJ, Kang YM, Moon CS, Joe MK, Lim JH, Suh YH, Song J, Jung MH: KLF4 positively regulates human ghrelin expression. Biochem J 2009, 420(3):403-411.

35. Bartelheimer AC: Die Bedeutung des Krüppel-like-Faktor 4 (KIf4) bei der oralen Infektion mit dem Parasiten Toxoplasma gondii, PhD Thesis. Berlin: Fakultät Charité-Universitätsmedizin; 2013.

36. Feinberg MW, Cao Z, Wara AK, Lebedeva MA, Senbanerjee S, Jain MK: Kruppel-like factor 4 is a mediator of proinflammatory signaling in macrophages. J Biol Chem 2005, 280(46):38247-38258.

37. Rosenzweig JM, Glenn JD, Calabresi PA, Whartenby KA: KLF4 Modulates Expression of IL- 6 in dendritic cells via both promoter activation and epigenetic modification. J Biol Chem 2013, 288(33):23868-23874.

38. Srivastava K, Cockburn IA, Swaim A, Thompson LE, Tripathi A, Fletcher CA, Shirk EM, Sun H, Kowalska MA, Fox-Talbot K, Sullivan D, Zavala F, Morrell CN: Platelet factor 4 mediates inflammation in experimental cerebral malaria. Cell Host Microbe 2008, 4(2):179-187.

39. Gahete MD, Cordoba-Chacon J, Hergueta-Redondo M, Martinez-Fuentes AJ, Kineman RD, Moreno-Bueno G, Luque RM, Castano JP: A novel human ghrelin variant (In1-ghrelin) and ghrelin-O-acyltransferase are overexpressed in breast cancer: potential pathophysiological relevance. PLoS One 2011, 6(8):e23302.

40. Jeffery PL, Duncan RP, Yeh AH, Jaskolski RA, Hammond DS, Herington AC, Chopin LK: Expression of the ghrelin axis in the mouse: an exon 4deleted mouse proghrelin variant encodes a novel $C$ terminal peptide. Endocrinology 2005, 146(1):432-440.

41. Kineman RD, Gahete MD, Luque RM: Identification of a mouse ghrelin gene transcript that contains intron 2 and is regulated in the pituitary and hypothalamus in response to metabolic stress. $J$ Mol Endocrinol 2007, 38(5):511-521.

42. Seim I, Lubik AL, Lehman M, Tomlinson N, Whiteside EJ, Herington A, Nelson C, Chopin L: Cloning of a novel insulin-regulated ghrelin transcript in prostate cancer. J Mol Endocrinol 2013, 50:1-14.

43. Bednarek MA, Feighner SD, Pong SS, McKee KK, Hreniuk DL, Silva MV, Warren VA, Howard AD, Van Der Ploeg LH, Heck JV: Structure-function studies on the new growth hormone-releasing peptide, ghrelin: minimal sequence of ghrelin necessary for activation of growth hormone secretagogue receptor 1a. J Med Chem 2000, 43(23):4370-4376.

44. Yang J, Zhao TJ, Goldstein JL, Brown MS: Inhibition of ghrelin Oacyltransferase (GOAT) by octanoylated pentapeptides. Proc Natl Acad Sci U S A 2008, 105(31):10750-10755.

45. Morozumi N, Hanada T, Habara H, Yamaki A, Furuya M, Nakatsuka T, Inomata N, Minamitake Y, Ohsuye K, Kangawa K: The role of C-terminal part of ghrelin in pharmacokinetic profile and biological activity in rats. Peptides 2011, 32(5):1001-1007.

46. Sayers EW, Barrett T, Benson DA, Bolton E, Bryant SH, Canese K, Chetvernin V, Church DM, Dicuccio M, Federhen S, Feolo M, Fingerman IM, Geer LY, Helmberg W, Kapustin Y, Krasnov S, Landsman D, Lipman DJ, Lu Z, Madden TL, Madej T, Maglott DR, Marchler-Bauer A, Miller V, Karsch-Mizrachi I, Ostell J, Panchenko A, Phan L, Pruitt KD, Schuler GD, et al: Database resources of the National Center for Biotechnology Information. Nucl Acid Res 2012, 40(Database issue):D13-D25. 
47. Arabian Oryx Genome Sequence. http://qatar-weill.cornell.edu/research/ oryxWeb.

48. Camacho C, Coulouris G, Avagyan V, Ma N, Papadopoulos J, Bealer K, Madden TL: BLAST+: architecture and applications. BMC Bioinformatics 2009, 10:421.

49. Gasteiger E, Gattiker A, Hoogland C, Ivanyi I, Appel RD, Bairoch A: ExPASy: the proteomics server for in-depth protein knowledge and analysis. Nucl Acid Res 2003, 31(13):3784-3788.

50. Edgar RC: MUSCLE: multiple sequence alignment with high accuracy and high throughput. Nucl Acid Res 2004, 32(5):1792-1797.

51. Menzies M, Ingham A: Identification and expression of Toll-like receptors 1-10 in selected bovine and ovine tissues. Vet Immunol Immunopathol 2006, 109(1-2):23-30.

52. Simon P: Q-Gene: processing quantitative real-time RT-PCR data. Bioinformatics 2003, 19(11):1439-1440.

doi:10.1186/s12917-014-0211-x

Cite this article as: Menzies et al:: Cloning and tissue distribution of novel splice variants of the ovine ghrelin gene. BMC Veterinary Research 2014 10:211.

\section{Submit your next manuscript to BioMed Central and take full advantage of:}

- Convenient online submission

- Thorough peer review

- No space constraints or color figure charges

- Immediate publication on acceptance

- Inclusion in PubMed, CAS, Scopus and Google Scholar

- Research which is freely available for redistribution 